\title{
HISTOCHEMICAL INVESTIGATION OF CONNECTIVE TISSUE IN CASES OF ACUTE RHEUMATISM
}

\author{
BY \\ A. I. STRUKOV AND G. V. ORLOVSKAYA \\ U.S.S.R. Academy of Medical Sciences, Moscow
}

(RECEIVED FOR PUBLICATION JULY 5, 1957)

The connective tissue is the chief place where the pathological rheumatic process takes place. The changes mainly affect its intercellular components. On the basis of this localization of the pathological lesions, rheumatism has been included among the so-called collagen diseases (Klemperer, 1950). The mechanism of development of the pathological processes in the intercellular substance of connective tissue can be understood only when there is a clear idea of the nature, structure, and correlations of collagen and the amorphous cementing substance, both of which play a principal role in the development of the rheumatic process.

The investigations made in recent years with the aid of physical, chemical, and histochemical methods have considerably advanced our concepts about collagen as a protein-polysaccharide complex (Randall, 1953; Randall, Both, Burge, FittonJackson, and Kelly, 1955; Jackson, 1954, 1957; Partridge, 1948; Orekhovich, 1952; Schmitt, Gross, and Highberger, 1955; Gross, Highberger, and Schmitt, 1955; Banga, Baló, and Szabó, 1956), and have helped in elucidating the processes taking place in the connective tissue in rheumatism. However, the concept that collagen was a monophasic system has hindered researchers from correctly analysing the observed phenomena.

A group of Soviet investigators have obtained new data on the structure of collagen; by biochemical, histochemical, roentgenological, and electronmicroscopic studies they have proved that collagen is a multi-phasic system consisting of many components (Tustanovsky, Seidess, Orlovskaya, and Michailov, 1954; Seidess, Tustanovsky, and Orlovskaya, 1955; Orlovskaya, Seidess, and Tustanovsky, 1956).

Collagen has therefore been divided into two phases: soluble (procollagen) and insoluble (collastromine). Obtained by precipitation from a solution, procollagen has all the properties of collagen fibrils (of collagen): it turns red when it is stained by Van Gieson stain, and its roentgenogram shows the characteristic interplane intervals of $2.9 \AA$ and $11.0 \AA$. Under the electron microscope it shows the same transverse bands.

In a roentgenogram, collastromine shows no ring at $2.9 \AA$ which is characteristic for collagen; it has no periodicity, does not turn red with Van Gieson stain, and shows a distinct metachromasia; staining with silver reveals argyrophilic fibres. The results of fractioning show collagen as at least a bi-phasic system; the known features of collagen in toto are determined by its content of procollagen.

Both procollagen and collastromine consist of many components. Collastromine contains polysaccharides and argyrophilic and non-argyrophilic proteins. The last make up the main mass of collastromine, and its amino acid content is almost identical with that of procollagen.

Procollagen has been separated into its protein and polysaccharide components. The polysaccharides include hyaluronic-acid-type polysaccharides and chondroitin-sulphate. After the separation of the polysaccharides, procollagen loses its transverse bands and is precipitated in the form of amorphous threads which, however, retain the collagen structure in the roentgenogram.

The reunion of individual polysaccharides with proteins and the subsequent dialysis of this compound again leads to the formation of fibrils with characteristic bands. Thus, it may be considered that the presence of transverse bands is connected with the combination of polysaccharide with procollagen. 
As a result of these investigations, a diagram of collagen structure was worked out (Fig. 1).

The multi-phasic character of collagen is also proved by observation of the formation of collagen in embryo. Histochemical and roentgenological data show that, in the early stages of the embryonic development of connective tissue, the fibrous structures are preformed as collastromine threads. The formation of structures of the collagen type is determined by the superimposition of procollagen on collastromine in a later stage of development.

Thus, polysaccharides take part in the formation of collagen up to the development of primary collagen fibrils which are of a bi-phasic structure.

This concept of collagen differs fundamentally from the accepted idea that collagen is a proteinmucopolysaccharide complex with a wholly uniform (mono-phasic) structure. The latter view is presented by Banga and others (1956), who consider that procollagen and metacollagen form a monophasic structure.

In our study of the pathological alterations of the connective tissue, we have made a more accurate analysis of the composition of the altered tissue and have examined the part played in these alterations not only by the entire collagen system but also by its separate components.

\section{Material}

Our observations are based on the post-mortem study of fifteen cases of genuine rheumatism. Four were children up to 10 years old, eight were aged from 15 to 20 years, and three were between 30 and 40 years old. The duration of the disease was: 1 to 2 years in three cases, 2 to 10 years in five cases, and over 10 years in the remaining seven cases. In all fifteen cases the predominant manifestation of the disease was cardiac disorder; in five cases, joint affections had also been observed at the onset of the disease.

\section{Method}

The heart was the main object of our investigations. We studied the valves, endocardium, myo- cardium, epicardium, and pericardium. The tissues were fixed in cold acetone $\left(+4^{\circ} \mathrm{C}\right.$. $)$ and immersed in paraffin. The serial sections were stained by the usual histological and histochemical methods and were also incubated with enzymes that specifically destroy definite components of the tissue. The following methods of staining were used: haematoxylin and eosin; Mallory; Van Gieson; toluidin blue; periodic acid+leucofuchsin, ShabadashHotchkiss (PAS); silver, Bielschowsky-Foote; periodic acid+silver, Bielschowsky-Foote (Tustanovsky and Orlovskaya, 1953); methyl-green-pyronine, Brachet (1947); staining of fibrin, Weigert; staining of elastic tissue by fuchselyne. The tissues were also treated with testicular hyaluronidase (purified by the method of Hahn and Tint), collagenase (Ktoxin- $\mathrm{Cl}$. perfringens), saliva, and crystalline ribonuclease.

\section{Results}

A detailed study of these cases of genuine rheumatism, based on the application of histochemical analysis, as well as our previous observations, showed that the rheumatic process cannot be reduced to a problem of granuloma. The alteration in the connective tissue of the heart valves, the endocardium, and the chordae tendineae, leading to the final development of sclerosis, occurs whether there is a granulomatous process or not, and is the end-result of the so-called "primary" sclerosis which is specific for rheumatism, as was pointed out by Talalayev (1932). However, Talalayev considered it to be less important in the development of rheumatic lesions than the "secondary sclerosis", which arises as the outcome of specific granulomata. Our observations show that, in the connective tissue of the endocardium and partially in the myocardium, sclerosing processes develop through a peculiar primary diffusive disintegration of the intercellular substance. But the dystrophic lesions of the tissue with the corresponding cellular reaction may or may not

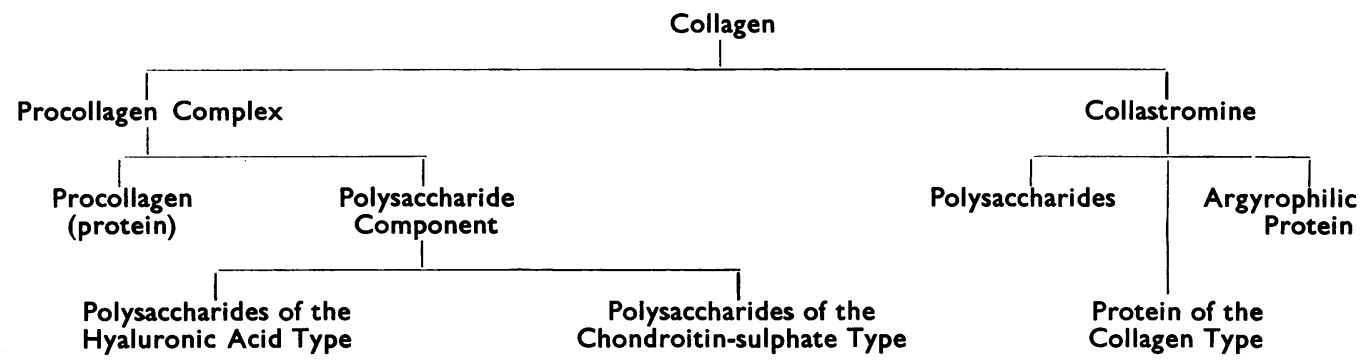

Fig. 1.-Diagram of the collagen complex. 
originate from such alterations of the connective tissue. In the latter case, the process of disintegration bears the same character.

The composition of the altered connective tissue has been examined at different stages in the pathological process. The initial change is designated as "mucoid swelling". At this stage the collagen bundles are swollen, yellowish, and light-refracting when stained with haematoxylin and eosin; toluidin blue stain causes a diffuse metachromasia which is absent during preliminary treatment with hyaluronidase. This metachromasia apparently depends both on the mucopolysaccharides of the cementing ground substance and on the polysaccharide components of the collagen complex. Van Gieson's stain gives the swollen bundles a bright red colour and the fibrous structure can hardly be distinguished. After treatment with collagenase, which (according to our data) specifically destroys the procollagen in tissue sections, but does not affect the unchanged collagen (Orlovskaya, Strukov, and Tustanovsky, unpublished), the fibres become more distinct. Van Gieson's stain does not affect the entire collagen complex, but only the procollagen, and therefore the disappearance of the diffused red colour after treatment with collagenase indicates the presence of diffused precipitated procollagen in such sections. This observation shows that, in the early stage of connective tissue alteration, the superficial phase of the collagen complex is disintegrated, procollagen is displaced, and metachromatic collagen polysaccharides appear. These alterations may be reversible.

In the next stage of connective tissue alteration ("hyalinosis" or "fibrinoid" degeneration), the tissue is not uniform. Two kinds of tissue area are observed, fibrin being deposited in one but not in the other. In the latter, we observed an intense metachromasia which disappeared after treatment with hyaluronidase; PAS ++ . Foote's stain gives an intense diffuse lilac colour, and Van Gieson's stain gives a bright diffused red. After treatment with collagenase, the red after Van Gieson staining and the blue-red after Foote staining weaken, and the fibrous structure becomes well-defined.

Other areas give a totally different histochemical reaction: yellow fields appear after Van Gieson staining, red spots after Mallory staining (Fig. 2), and a dirty-blue after staining with toluidin blue; PAS ++ to +++ ; when silvered the collagen bundles become argyrophilic. These areas contain deposits of fibrin (Fig. 3), which cause the colour changes. According to our observations, fibrin in itself is argyrophilic and PAS is positive. This has also been confirmed by Dempsey (1950) and by Gitlin, Craig, and Janeway (1957).

In longstanding cases of disease, the connective tissue alterations acquire a still more motley character. Areas of great density appear together with areas where swelling and homogenization are prevalent. In some places there is intensive metachromasia (Fig. 4), and in others a dirty-blue

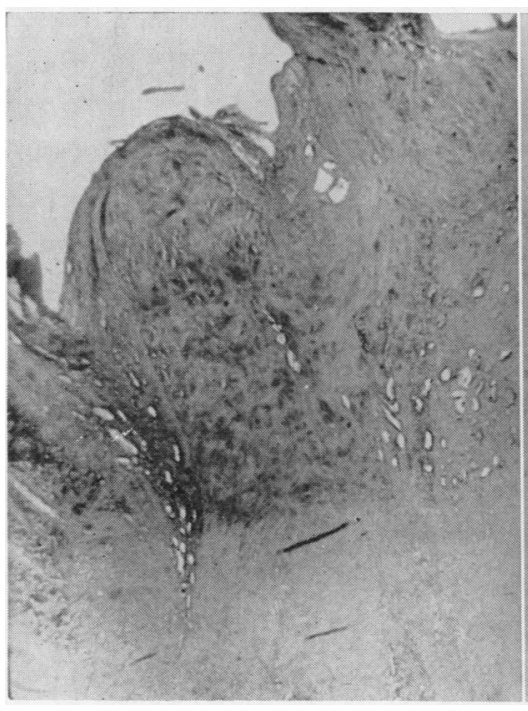

Fig. 2.-Mitral valve. Hyalinized connective tissue at the base of the valve. Mallory. Red colouring of fibrin deposits. $\times 60$.

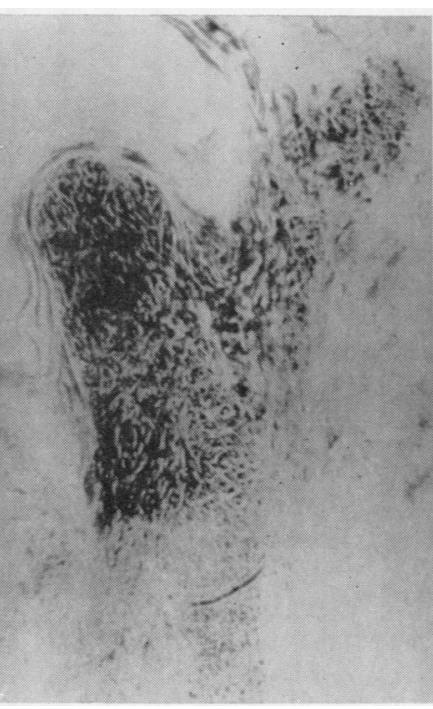

Fig. 3.-Same preparation as Fig. 2. Weigert staining of fibrin. Local deposits of fibrin coloured in deep blue. $\times 60$.

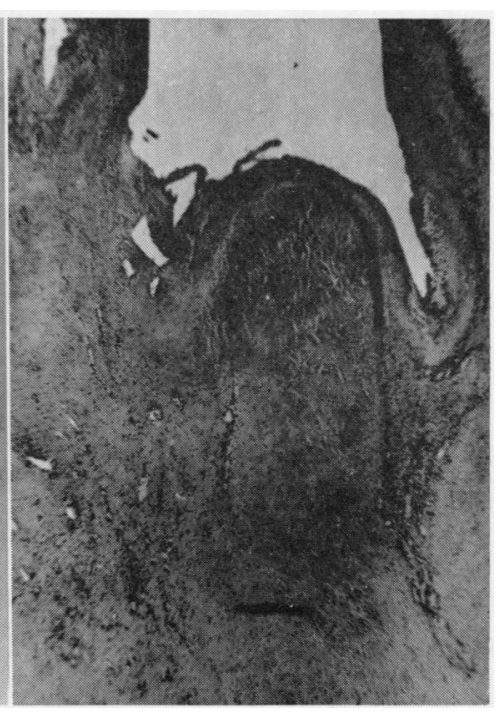

Fig. 4.-Same preparation as Fig. 2. Toluidin-blue. Heterogeneous intensive metachromasia. $\times 60$. 
colouring. The PAS reaction is not so intense. Incubation with hyaluronidase leads to the disappearance of metachromasia in some places, though it is retained elsewhere, which indicates the presence of acid mucopolysaccharides and also of glucoproteins or other compounds that are not depolymerized by hyaluronidase. Considerable localized deposits of fibrin are found in such tissue. After the collagenase treatment of tissue in places where no deposits of fibrin were found, the red colouring due to Van Gieson staining weakens sharply (Figs 5 and 6), and argyrophilic collastromine fibres appear.

Thus, in the "hyalinized" tissue, we discovered an excessive amount of mucopolysaccharides of different types and an accumulation of procollagen, which was comparatively easily destroyed by collagenase in some places and could not be destroyed in others. This is an indication of the disintegration of collagen fibres. Considerable deposits of fibrin were also found here.

Morphological changes in the connective tissue manifest themselves by the absence of collagen bundles and the appearance of dense homogeneous areas. This causes different degrees of disorganization of the connective tissue. A profound disturbance of this nature in the structure of the connective tissue was observed in the heart valves, endocardium, and chordae tendineae.

The alterations in the perivascular and interstitial tissues of the myocardium are similar but less marked. The perivascular connective tissues and the interstitial tissues of the myocardium are loosened and oedematous. Among the loose collagen bundles are some groups in which massive deposits of fibrin are formed (Fig. 7, opposite). They are thickened and homogeneous; with Van Giesen's stain they become bright red with yellow spots; with Mallory's stain they become a homogeneous blue with red spots; with toluidin blue they become a dirty-blue; with Foote's stain they become lilacblack, or argyrophilic fibres appear (Fig. 8, opposite). Similar changes in the collagen fibres of perivascular connective tissue were observed by Stojalowski and Krygier (1956) in the early phases of rheumatic disease. The significance of these observations will now be discussed.

\section{Discussion}

Our observations show that collagen fibres play a direct part in the fibrinoid changes of the connective tissue. Klemperer (1954) believes that physical and chemical changes in the components of collagen occur during fibrinoid degeneration; the ground substance plays a secondary role in this process. The opposite view, held by a number of investigators (Altshuler and Angevine, 1949; RubensDuval and Villiaumey, 1952), is that the ground substance of the connective tissue plays the major role in the development of fibrinoid changes.

Let us examine the composition of the altered con. nective tissue designated "fibrinoid necrosis". Such areas are located in the endocardium and the walls of vessels. In their centre they have granular masses and along their periphery are seen characteristic large cells with basophilic cytoplasm; Van Gieson's stain gives the granular material a yellowish-brown colour, and red shreds of fibre appear; Mallory's stain produces red grains and blue shreds of fibre; Foote's

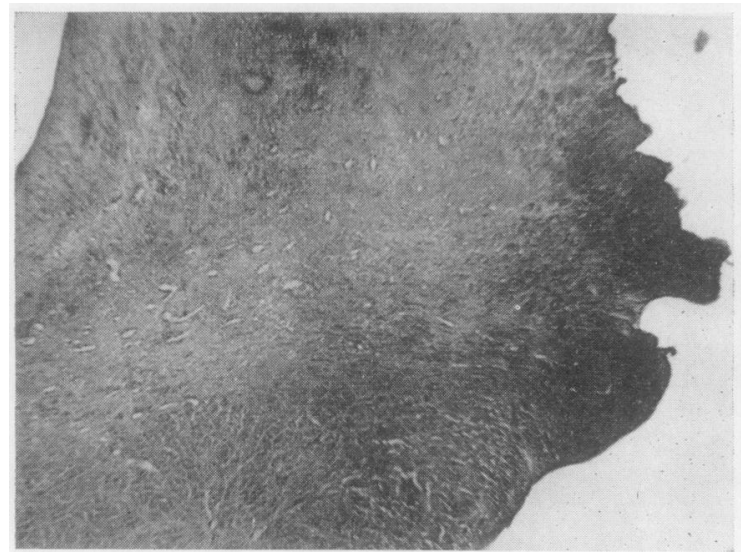

Fig. 5.-Same preparation as Fig. 2. Van Gieson. Bright red colour of irregular intensity. $\times 60$.

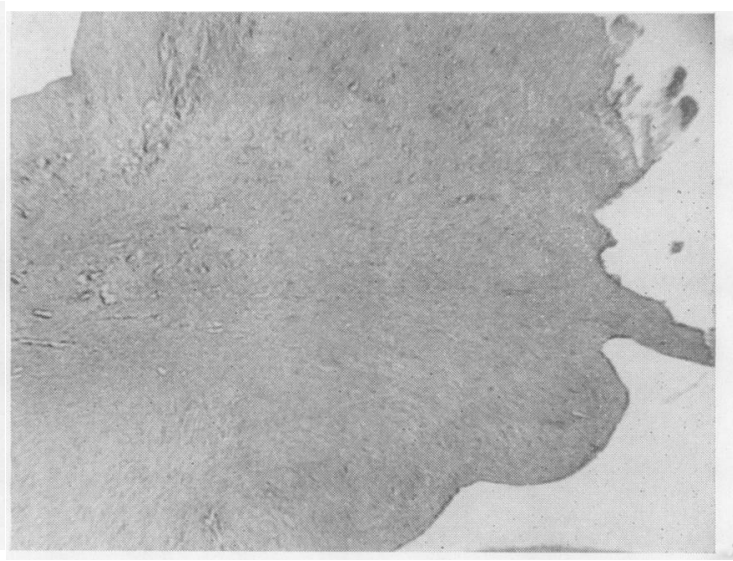

Fig. 6.-Same preparation as Fig. 2. Van Gieson staining after treatment with collagenase. After disappearance of procollagen the connective tissue is much less intensely coloured, and in places the colour is yellow. $\times 60$ . 


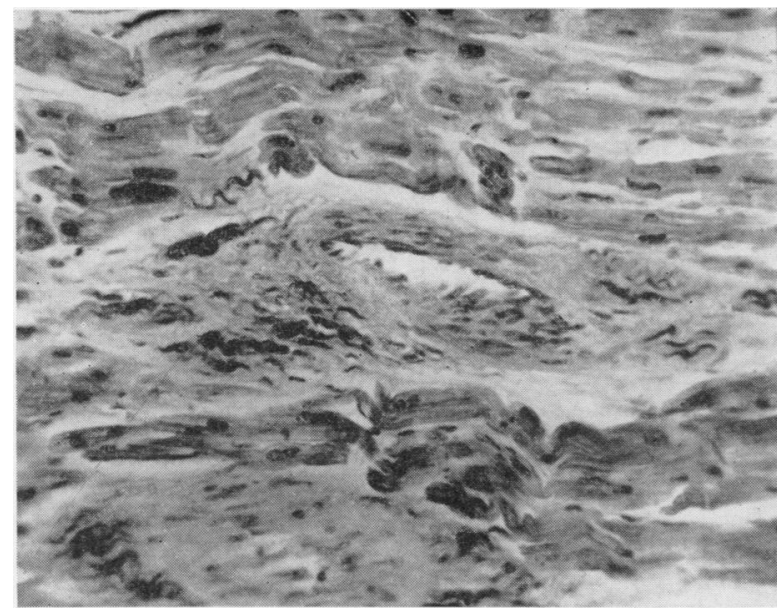

Fig. 7.-Fibrin deposits on the surface of collagenous fibre in the perivascular connective tissue. The collagenous fibres took a very dark colour. Weigert. $\times 200$.

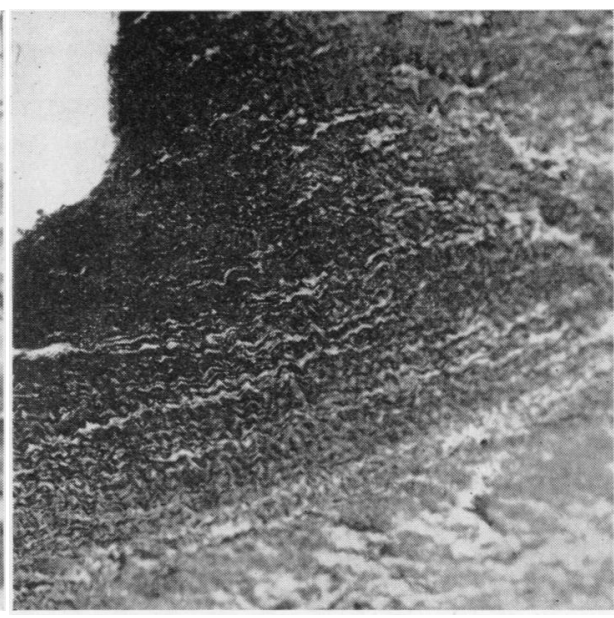

Fig. 8.-Fibrin deposits on altered collagenous fibres. The fibres have become argyrophilic. Foote. $\times 200$. stain reveals shreds of homogeneous collagen bundles; toluidin blue stain gives orthochromasia; PAS +; destruction of the elastic stroma can be observed. Here fibrin is either not found at all or is found in small deposits on the collagen shreds (it is possible that the fibrin previously deposited was undergoing autolysis).

Such areas, with necrotic changes in the centre and large cells in the periphery, were regarded by Talalayev (1932) and Klinge (1933) as specific manifestations of the genuine rheumatic process and are histogenetically identified with myocardium granulomata. We shall deal with the latter below; here we shall emphasize only the fact that, in the lesions developing in the endocardium and in the walls of vessels, the necrosis affects the connective tissue as can be determined by the presence of residues of collagen fibres. "Fibrinoid necrosis" is characterized by profound dystrophic alterations in the connective tissue, which is subject to necrosis and, like other necrotic material, is resorbed by histiocytes.

We have examined the various types of alteration in the connective tissue of the heart in cases of genuine rheumatism, and have made certain observations on the mechanism governing these alterations.

During exacerbations of rheumatic disease an increased exudation of plasma into the connective tissue (oedema) takes place as a result of the increased permeability of the capillaries. The composition of the blood plasma in hyperergic conditions and, in particular, during acute stages of inflammatory rheumatism, is substantially different from normal. There is a relative increase of the globulin fractions, especially of the gamma-globulins, as well as of fibrinogen (Wilson and Lubschez, 1948; Hansen, 1954; Dzyak, 1954). The blood mucopolysaccharides increase noticeably (Hadidian and Pirie, 1948; Rosenberg and Schloss, 1949). The oedema of the connective tissue and the increased acidity observed during acute inflammatory processes apparently call forth a partial disintegration of the collagen complex: displacement of procollagen and the appearance of polysaccharides. This may also be facilitated by the action of depolymerizing enzymes, in particular, by hyaluronidase, whose activity increases in rheumatic patients, especially during exacerbations (Dorfman, 1950; Good and Glick, 1950; Zalessky, 1955; Egorova and Petrova, 1957).

Thus, various substances accumulate in the connective tissue, which have been released from the basic structure of the connective tissue or brought in by the blood owing to the increased exudation of the abnormal blood plasma. These substances include procollagen and other proteins and mucopolysaccharides (hyaluronic acid and sulphated mucopolysaccharides) liberated from the collagen complex; proteins and polysaccharides of the ground substance: polysaccharides of the chondroitin tissue of the heart valves (Tretyakov, 1916; Deiss and Leon, 1955); blood proteins and polysaccharides; and products of cellular activity and cellular disintegration (enzymes and nucleoproteins).

If the rheumatic process is interrupted at the end of an acute attack, the accumulation of abnormal substances is resorbed, and full or partial restoration of the normal structure takes place. However, we 
know that rheumatism is characterized by a polycyclic, latent course, and once the structure of the connective tissue is altered the alterations will continue to develop with superimposition of new phases of destruction during exacerbations. In the affected areas there occur changes in plasma proteins (with the available methods we were able to find only the products of fibrinogen changes).

Apparently different processes occur here. On the one hand, fibrinogen changes into fibrin of the usual type as a result of thrombin activity, and threads of fibrin are precipitated. On the other hand, the acid-sulphide mucopolysaccharides, which possess a high surface activity and which appear in increased amounts in the altered connective tissue, may interact with the plasma fibrinogen and thus form insoluble free fibrinogen derivatives (Thomas, Smith, and von Korff, 1954). Fibrinogen may be deposited on the surface of collagenous fibres in which the connexions between the polysaccharides and procollagen are partially destroyed.

In their turn, the proteins and polysaccharides from the disintegrated collagen fibres and the ground substance may form new compounds, such as abnormal deposits of procollagen on chaotically built-up collastromine and areas of procollagen sedimentation combined with the excessive mucopolysaccharides.

Thus new abnormal protein and polysaccharide compounds are formed which are characterized morphologically by the absence of shaped fibrous bundles and by the appearance of pathological structures.

Proceeding from this idea of the pathogenesis of the destructive processes in rheumatism, let us examine the concept of "fibrinoid degeneration" of connective tissue. The composition of tissue in the areas of "fibrinoid degeneration" and in the areas of "fibrinoid necrosis" is different. In the former, the connective tissue contains fibrin-its constant component; in the latter, fibrin cannot be found by histochemical methods. In "fibrinoid degeneration" we observe mainly alterations in the proteins and polysaccharides of the connective tissue and interstitial fluid, which form abnormal compounds. In fibrinoid necrosis there is extensive destruction of tissue. However, in the literature, both these types of tissue alteration are known by the single name of fibrinoid, or, alternatively, only one of these types is described and defined as fibrinoid. This has led to the formulation of different theories about fibrinoid, depending on the material by which this phenomenon was studied.

There can be no common designation for fibrinoid changes of the connective tissue, and there are no grounds for including "fibrinoid" in a group of substances with definite chemical properties. The idea of "fibrinoid degeneration" includes several connective tissue changes caused by the destruction of collagen fibre with the disintegration of the collagen complex and the formation of anomalous compounds with elements of the ground substance and components of plasma, primarily with fibrinogen.

At the same time, local necrosis of the connective tissue may occur in which a different kind of phenomenon occurs.

In chronic rheumatic disease with repeated attacks, both kinds of phenomena may be superimposed; this results in extensive destruction of the connective tissue and the formation of the distorting sclerosis which is characteristic of genuine rheumatism.

The described changes in the perivascular connective tissue are apparently of the same nature as "fibrinoid degeneration". The deposition of fibrin is indirectly associated with the blood supply and is evidently the result of fibrinogen alterations in the interstitial fluid. Fibrinogen is normally present in the interstitial fluid, but when there is an increased escaping of plasma proteins (oedema) it is found in much larger quantities. The mechanism of fibrin deposition is evidently the same as that described above.

The appearance of argyrophilic fibres is, according to Schlossmann (1942) and Glynn and Loewi (1952), a characteristic feature distinguishing fibrinoid from banal deposits of fibrin. This phenomenon has no common designation and according to our observations includes two different phenomena. On the one hand we see the destruction of the collagen complex under the influence of the softening and digestive action of oedema, histolytic enzymes, and so on, and argyrophilic proteins of collastromine become visible (Orlovskaya, 1956). Such is the mechanism of the appearance of the argyrophilic network in rheumatic granulomata (Klinge, 1933), or during fibrinoid necrosis of the vascular walls and submucosa of the intestine in enteritis necroticans (Brockhaus, 1953). On the other hand, fibres of the collagen bundles become argyrophilically stained, especially where there are massive deposits of fibrinogen. Here, the fibrinogen evidently combines with the reacting groups of collagen fibres liberated during collagen disintegration and is diffused on their surface, so producing argyrophilia (Fig. 7). Such is the mechanism of argyrophilia observed by Glynn and Loewi (1952).

In studying the specific myocarditis, which, according to Aschoff (1904) and Talalayev (1932), 
forms the basis of the tissue reaction in rheumatism, we were interested in elucidating two problems: the nature of the proteins in the granulomata of the myocardium and the character of the granuloma cells.

In florid granulomata, in addition to large cells with polymorphic nuclei and basophilic cytoplasma, we observed "cells" with abundant light cytoplasm and a swollen nucleus. The use of various staining methods established that the "cells" of the second type possessed all the tinctorial properties of the muscle fibres of the myocardium; a greenish-blue colour after staining with toluidin blue, which is unusual for any other tissue, is particularly characteristic. Granular masses that accumulate between the cells of granulomata have the same colour reaction (toluidin blue-a characteristic greenishblue colour), which shows its myogenic origin. The disintegrated masses contain no material originating from the connective tissue.

No "cells" of the second type are observed in the older granulomata; as they mature, the basophilic cells decrease in size, lengthen out, and turn into fibroblasts; meanwhile the "cells" of the second type, evidently residual muscle fibre, disintegrate and form a granular mass that is resorbed by the cells of the first type. Thus, in myocardial granulomata, the protein "masses" are in the main of myogenic origin on contrast to the specific nodules in the endo- cardium and vascular walls, which include products of the disintegration of fibrous connective tissue.

Cells of the histiocytic type are active elements of granulomata. Our observation that they contained ribonucleic acid testifies to their high activity.

The histiocytic cells of the granulomata contain in their cytoplasma pyroninophilic granules which are destroyed by ribonuclease. Regular dynamic changes in the distribution and character of these granules may be observed during the development of granulomata. The cytoplasm of cells in young nodules does not have precise limits; the pyroninophilic granules are large, loose, and dull (Fig. 9). As the cells mature, they become denser and lengthen out, and groups are disposed in a definite direction; the colouring, density, and quantity of pyroninophilic granules of cytoplasma increase and pyroninophilic nuclei become visible. Thus, at first, in the period of the maximum activity of the cells, they contain a relatively small quantity of ribonucleic acid, but later, when they acquire a fibroblastic function, a considerable accumulation of this acid is observed. The quantity of ribonucleic acid is possibly related to changes in the functions of the histiocytes - they are at first lytical and later plastic (Brachet, 1947; Caspersson, 1939, 1947; Kedrovsky, 1951; Gale, 1956); in this case, the function consists in the building up of the connective tissue.

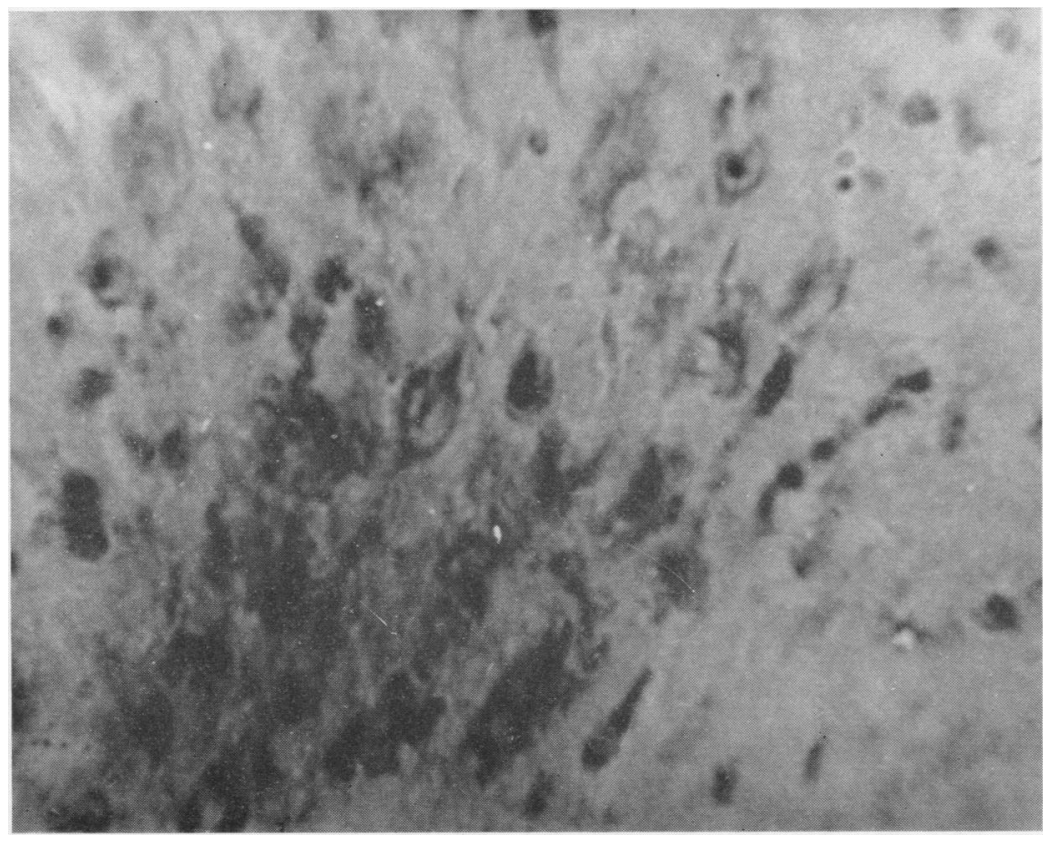

Fig. 9.-Granuloma in the myocardium. Brachet staining. Accumulations of grains of ribonucleic acid in cell cytoplasm. Cell limits not clear. $\times 200$. 


\section{Summary}

(1) The structure of collagen is shown to be bi-phasic, consisting of soluble procollagen and insoluble collastromine. Each of these phases consists of many components.

(2) Under various pathological influences, the collagen complex may be broken up into its various components. The degree of disorganization and the possibility of restoring the normal structural relationships of the tissues are dependent on the character, degree, and duration of the pathological process, the reactivity of the body, and the toxic influence of the pathogenic agent.

(3) A special feature of the involvement of the connective tissues in acute rheumatism is the permanence and intensity of the alterations, leading to the formation of new abnormal compounds between the components of the connective tissue itself and the substances entering from the blood plasma. The resulting pathological tissue alterations (hyalinosis, sclerosis) determine the gravity of the connective tissue changes in rheumatic carditis.

\section{REFERENCES}

Altshuler, C. H., and Angevine, D. M. (1949). Amer. J. Path., 25, 1061 .

Aschoff, L. (1904). Verh. dtsch. Path. Ges., 8, 46.

Banga, I., Baló, J., and Szabó, D. (1956). Acta physiol. Acad. Sci. hung., 9, 61,

Brachet, J. (1947). Symp. Soc. exp. Biol. (Camb.), 1, 207.

Brockhaus, L. (1953). Virchows Arch. Path. path. Anat., 324, 338

Caspersson, T. (1939). Chromosoma (Berl.), 1, 147.

- (1947). Symp. Soc. exp. Biol. (Camb.), 1, 127.

Donzelot, E., and Kaufmann, H. (1950). Arch. Mal. Coeur, 43, 229.

Deiss, W. P., and Leon, A. S. (1955). J. biol. Chem., 215, 685.

Dempsey, E. W. (1951). "Connective Tissues." Transactions of the First Conference, 1950, Josiah Macy, Jr., Foundation. New York.

Dorfman, A. (1950). Ann. N.Y. Acad. Sci., 52, art. 7, 1098.

Dzjak, W. (1954). "Blood Level of Protein in the Rheumatic Diseases." Dissertation Dnepropetrovsk, U.S.S.R

Egorova, A. I., and Petrova, E. N. (1957). Klin. Med. (Mosk.),

Gale, E. (1956). "Proceedings of Third International Congress of Biochemistry, Brussels, 1955", p. 345.

Gitlin, D., Craig, J., and Janeway, C. (1957). Amer. J. P.th., 33, 55.

Glynn, L., and Loewi, G. (1952). J. Path. Bact., 64, 329.

Good, R. A., and Glick, D. (1950). J. infect. Dis., 86, 38. Proc, nat.

Gross, J.. Highberger, J. H., and Acad. Sci. (Wash.), 41,

Hadidian, Z., and Pirie, N. W. (1948). Biochem. J., 42, 266.

Hansen, K. B. (1954). Acta med. Scand., 147, 447.

Jackson, D. S. (1954). Biochem. J., 56, 699.

(1957). Ibid., 65, 277.

Kedrovsky, B. V. (1951). Usp. sovr. Biol., 31, 38

Klemperer, P. (1950). Amer. J. Path., 26, 505.

- (1954). In "Connective Tissue in Health and Disease", ed. G. Asboe-Hansen, p. 251. Munksgaard, Copenhagen.

Klinge, F. (1933). Ergebn. allg. Path. path. Anat., 27, 27.

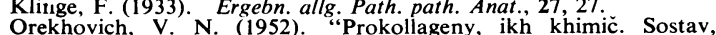
svojstva i biol. Rol.", Moscow.

Orlovskaya, G. V. (1956). Arkh. Patol., 18, No. 1, p. 68 Seidess, A. L., and Tustanovsky, A. A. (1956). C.R. Acad Sci., U.R.S.S., 111, 1396.

Strukov, A. I., and Tustanovsky, A. A. "Sbornic rabot po gistokhimii.", (V pečati.)

Partridge, S. M. (1948). Biochem. J., 43, 387.

Randall, J. T. (1953). "Nature and Structure of Collagen." (Faraday

Society.) Butterworth, London.
Booth, F., Burge, R. E., Jackson, S. Fitton, and Kelly, F. C. (1955). Symp. Soc. exp. Biol. (Camb.), 9, 127.
Rosenberg, C., and Schloss, B. (1949). Amer. Heart J., 38, 872.

Rubens-Duvai, A., and Villiaumey, J. (1952). Rev. Rhum., 19, 514

Sallessky, T. D. (1955). Sovetsk. Med., 12, 3

Schlossmann, N. C. (1942). Arch. Path. (Chicago), 34, 365.

Schmitt, F. O., Gross, J., and Highberger, J. H. (1955). Symp. Soc. exp. Biol. (Camb.), 9, 148.

Seidess, A. L., Tustanovsky, A. A., and Orlovskaya, G. V. (1955). C.R. Acad. Sci. U.R.S.S. 104, 563.

Stojalowski, K., and Krygier, A. (1956). Roczn. pom. Akad. Med. Swierczewskiego, $2,353$.

Talalayev, V. T. (1932). "Ostryj Revmatizm." Moscow.

Thomas, L., Smith, R. T., and Korff, R. von (1954). Proc. Soc. exp. Biol. (N.Y.). 86, 813 .

Tretyakov, D. (1916). Russk. Arkh. Anat., 1, 271 (p. 233 in French edition of the same Journal, Arch, russ. Anat.).

Tustanovsky, A. A., and Orlovskaya, G. V. (1953). Arkh. Patol., 15, No. 3, p. 32 .

_- Seidess, A. L., Orlovskaya, G. V., and Michailov, A. N. (1954). C.R. Acad. Sci. U.R.S.S., 97, 121.

Wilson, M. G.. and Lubschez, R. (1948). Pediatrics, 2, 577.

Recherches biochimiques sur le tissu conjonctif dans des cas de vrai rhumatisme

RÉSUMÉ

(1) On montre que la structure du collagène est bi-phasique, comprenant le procollagène soluble et la collastromine insoluble. Chacune de ces phases se compose de plusieurs parties.

(2) Soumis à de différentes influences pathologiques, le complexe collagène peut se décomposer en différents constituants. Le degré de désorganisation et la possibilité de restaurer les rapports structuraux normaux des tissus dépendent du caractère, du degré et de la durée du processus pathologique, de la réactivité du corps et de l'influence toxique de l'agent pathogène.

(3) Un trait particulier de l'implication des tissu@ $\overrightarrow{0}$ conjonctifs es la permanence et l'intensité des altération menant à la formation de nouveaux composés anormau entre les constituants du tissu conjonctif propre et les substances qui y viennent du plasma. Les altérations pathologiques des tissus (dégénérescence hyaline, sclérose) qui en résultent, déterminent la gravité des désordres des tissus conjonctifs dans la cardite rhumatismale.

\section{Investigaciones bioquímicas sobre el tejido conjuntivo en casos de verdadero reumatismo}

\section{Sumario}

(1) Se muestra que la estructura del colageno es bifásica, comprendiendo el procolageno soluble y la colastromina insoluble. Cada de estas fases se compone de varios constituyentes.

(2) Bajo varias influencias patológicas, el complejo colageno puede dividirse en varios constituyentes. El grado de desorganización y la posibilidad de restablecer las relaciones estructurales normales de los tejidos dependen del caràcter, del grado y de la duración del proceso patológico, de la reactividad del cuerpo y de la influencia tóxica del agente patógeno.

(3) Un rasgo particular de la implicación de los tejidos conjuntivos reside en la permanencia y la inten- 0 sidad de las alteraciones, llevando a la formación de nuevos compuestos anormales entre los constituyentes del tejido conjuntivo propio y las substancias viniendo del plasma. Las alteraciones patológicas de los tejidos (hyalinosis, esclerosis) resultantes, determinan la gravedad de las alteraciones de los tejidos conjuntivos en la carditis reumática. 